\title{
MALDI-TOFMS による合成有機成分のイメージング測定
}

\author{
佐藤 幸司 $^{\circledR 1}$, 吉田 和之 ${ }^{1}$, 森永 浩子 ${ }^{2}$, 山口 亮 ${ }^{2}$, 小 河 潔 ${ }^{2}$
}

\section{1 緒言}

高分子材料中に含まれる添加剤のような合成有機物は, 材料の劣化抑制に寄与していることから，材料開発におい て，その量的並びに分散状態の把握が重要である。 また, 洗剤中の界面活性剂のような合成有機物については，その 効果を計るためには, 対象物への付着や浸透量の程度を評 価することが重要となる.これらの分析, 評価においては, 一般的に溶媒抽出法等により添加剤を分離し機器分析する ことによって, 添加剤の構造や含有量を解析する方法が確 立されている ${ }^{1}$ 。これは，材料の平均的な組成を評価する ことが可能であり，材料全体の変化を捉えるという観点か らは有効な方法である. しかし, 材料中の合成有機物の偏 在化，局在化の有無を評価することはできないため，次の ような方法で行っている. 例えば添加剤の偏析等, 特定成 分の位置情報を評価する方法として, 材料を切削後にフー リ工変換赤外分光 (FT-IR) で表面や断面の官能基情報をイ メージング評価する方法や, 飛行時間型二次イオン質量分 析（TOF-SIMS）やX 線光電子分光（XPS）で極表面や梁 さ方向の分子フラグメントや元素組成の分布をイメージン グ解析する方法等である ${ }^{2}$. ただし，FT-IRでは，官能基情 報をイメージ化できたとしても，類似化合物があった場 合, 評価できない欠点があった，また，TOF-SIMS やXPS では，狭い範囲しか分析できない問題があった．この問題 に対して, マトリックス支援レーザー脱離イオン化-飛行 時間型質量分析（MALDI-TOFMS）を用いれば，広範囲な 測定面の質量スペクトルで評価できる利点がある。現状, MALDI-TOFMS によるイメージングは, 主に生体材料中の 代謝物の解析に用いられており ${ }^{3)}$, 代謝物の分布状態解析 や細胞由来タンパク質のトリプシン消化産物 ${ }^{4}$ や脂質の分 布解析等, 生体切片の評価法として実用化されている ${ }^{5) 6}$. これは, MALDIがソフトなイオン化法であり,アミド結合 やエーテル結合といった構成官能基がほぼ同じ生体材料に

\footnotetext{
${ }^{\circledR}$ E-mail : satou.kc@om.asahi-kasei.co.jp

${ }^{1}$ 旭化成株式会社基盤技術研究所 : 416-8501 静岡県富士市鮫島 2-1

2 株式会社島津製作所基盤技術研究所 : 619-0237 京都府相楽郡 精華町光台 3-9-4
}

おいては，一定条件で高分子量体をイオン化しやすいとい う特徴を活かしたものである. しかしながら, 合成有機成 分への適用報告はほとんど見当たらなかった。一方， MALDI-TOFMS は, 材料系の合成有機成分の構造解析に活 用されており，試料表面や切片中の合成有機成分もうまく イオン化することができれば7，位置情報をイメージ化可 能であり, 材料評価法として重要な情報が得られる.

そこで著者らは, 合成有機成分を含む試料切片につい て, マトリックスを蒸着させた MALDI-TOFMS によるイ メージング法を検討した，その結果，本法で添加剤等の合 成有機成分の分布状態解析に扔いて良好な結果が得られた ので報告する.

$$
2 \text { 実験 }
$$

\section{$2 \cdot 1$ 装 置}

試料の MALDI マススペクトルの取得及びイメージング 解析には, 光学顕微鏡と質量分析計を一体化し, 形態画像 と分子分布画像を重ね合わせることが可能な島津製作所製 の質量顕微鏡（iMScope）試作機を用いた Nd:YAG THG（波長 $355 \mathrm{~nm}$ ), $7.1 \mu \mathrm{m}$ ピッチ, $400 \mathrm{~Hz}, 80$ ショット/ピクセル, positiveモードで測定を行った. また, マトリックスの蒸着は，島津製作所で試作した抵抗加熱式 真空蒸着装置内のヒーターにマトリックスを置き, 温度 $160{ }^{\circ} \mathrm{C}$ で, 加熱, 減圧することで, 対向の酸化インジウム スズ (Indium-Tin-Oxide: ITO) スライドガラス (ALDRICH 製）に固定した試料（切片）に摬して行った。蒸着時間は, イオンの感度が高くなる 2 分間とした（マトリックス想定 厚み; $1.7 \mu \mathrm{m})$.

なお，イメージング測定の際，評価対象とするイオンを 明確にするため, 後述の添加剤やへアケア剂（リンス）に ついてマトリックス溶液と混合し，島津製作所製の AXIMA-CFR plus [窒素レーザー（波長 $337 \mathrm{~nm}$ ), positive モード] で測定し, その MALDI マススペクトルを確認し た.

\section{$2 \cdot 2$ 試 料}

$2 \cdot 2 \cdot 1$ 光学用多層フィルム Fig. 1 に示すような約 $200 \mu \mathrm{m}$ のポリプロピレンコア層の両側に Table 1 に示す 


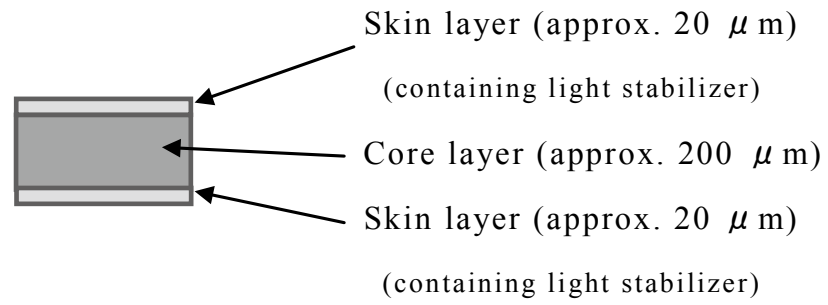

Cross section of film

Fig. 1 Schematic drawing of multi-layer optical film structure

3 種の光安定剂（商品名: Tinuvin1577F, Tinuvin 234, Tinuvin 850）を含む約 $20 \mu \mathrm{m}$ のスキン層をラミネートし た 3 層構造を有するフィルムで検討を行った.

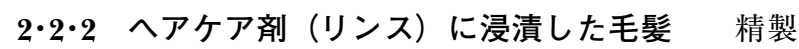
水で約 1000 倍に希釈した市販のへアケア剂（リンス）に, 根元部分を束ねた長さ約 $20 \mathrm{~cm}$ の人間の毛髪束をそれぞれ 1 分, 30 分, 24 時間浸漬し, 浸漬時間経過後, 毛髪表面を キムワイプで軽く抑え水分を拭き取り，測定に用いた。 ま た, 参照試料として薬液に浸漬しない毛髪も一緒に評価し た。

\section{$2 \cdot 3$ 試 薬}

MALDI のマトリックスとして，2,5-ジヒドロキシ安息香 酸（DHB）（ARDRICH 製，98\%）を用いた。光学用多層 フィルムに添加されている各光安定剤の MALDI マススペ クトルを確認するため, 市販品 (BASF 製) を用いた. へ アケア剤（リンス）の MALDI マススペクトルの確認には, ヘアケア剂 (リンス) を浸漬した毛髪表面の測定を行った. ヘアケア剂（リンス）に浸漬した毛髪は, 電子顕微鏡用エ ポキシ樹脂 Quentol 812 (日新 EM製) を用いて包埋を行っ た。

\section{$2 \cdot 4$ 測 定}

$\mathbf{2 \cdot 4 \cdot 1}$ 光学用多層フィルム 液体窒素で冷却したク ライオミクロトーム（LEICA 製 UCT EMFCS）に多層フィ ルムをセットし, ガラスナイフにて厚さ $3 \mu \mathrm{m}$ のフィルム 切片を作製した。切片の四隅にメンディングテープを貼り 付け, 透明電動膜（ITO）スライドガラスに固定した後, 前述の装置にてマトリックスを蒸着し，質量顕微鏡 (iMScope) 試作機で MALDI-TOFMS によるイメージング 解析を行った. また, 各光安定剂の THF 溶液を調製し, AXIMA-CFR plusにて MALDI マススペクトルを測定し，プ ロトン付加イオンとスペクトルパターンの確認を行った.

$\mathbf{2 \cdot 4 \cdot 2}$ ヘアケア剂（リンス）に浸漬した毛髮へアア

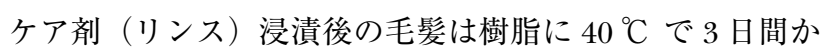
けて包埋した後, トリミング処理し, ミクロトーム
Table 1 Chemical structure of light stabilizers

High molecular weight compound with a
hindered amine structure in its host
framework

（LEICA 製 UCT）で厚さ $5 \mu \mathrm{m}$ の切片にした．切片の四隅 にメンディングテープを貼り付け，ITO スライドガラスに 固定した後，前述の装置にてマトリックスを蒸着し，質量 顕微鏡（iMScope）試作機で MALDI-TOFMS によるイメー ジング解析を行った。併せて，ヘアケア剂（リンス）に浸 漬した毛髪を ITO スライドガラス上に貼り付けた導電性 粘着テープ上に横に並べて固定し，切片と同じようにマト リックス（DHB）を蒸着後に MALDI 積算スペクトルの測 定を行った.

\section{3 結果と考察}

\section{$3 \cdot 1$ 光学用多層フィルムのイメージング測定}

3 種類の光安定剂の分布状態をイメージ化するため, フィルム断面の MALDI 積算マススペクトルを測定し, Tinuvin 1577F, Tinuvin 234 及び Tinuvin 850 の各 MALDI マススペクトル測定で確認された特徴的なプロトン付加イ オンである $m / z 426,448,512$ でイメージング評価した. 検出されるイオンを確認するためにAXIMA-CFR plus で測 定したオリゴマー構造を有する Tinuvin 850 のスペクトル を Fig. 2 に示した. Fig. 3 に示すように, Tinuvin $1577 \mathrm{~F}$ と Tinuvin 234 は表層のスキン層に多く含有するものの, コ ア層にも分布していることが確認された. 一方, Tinuvin 850 はスキン層よりもコア層に分布しており，フィルム全 体に分散している様子が確認された。 なお, 両コア層から 内部移行しているイメージング結果が得られたことから, 切片作成時のナイフによる持ち込みでなく，正規な添加剂 分布をモニタリングできていると判断した.

各光安定剤は, 光劣化が開始される原因となる有害な紫 外線を吸収する紫外線吸収剂としての効果があるため7), スキン層への添加が行われているが，ラミネート時の加熱 とフィルム成型後の経時によって, スキン層中の光安定剤 がコア層に溶出, 移行していることが確認された. 


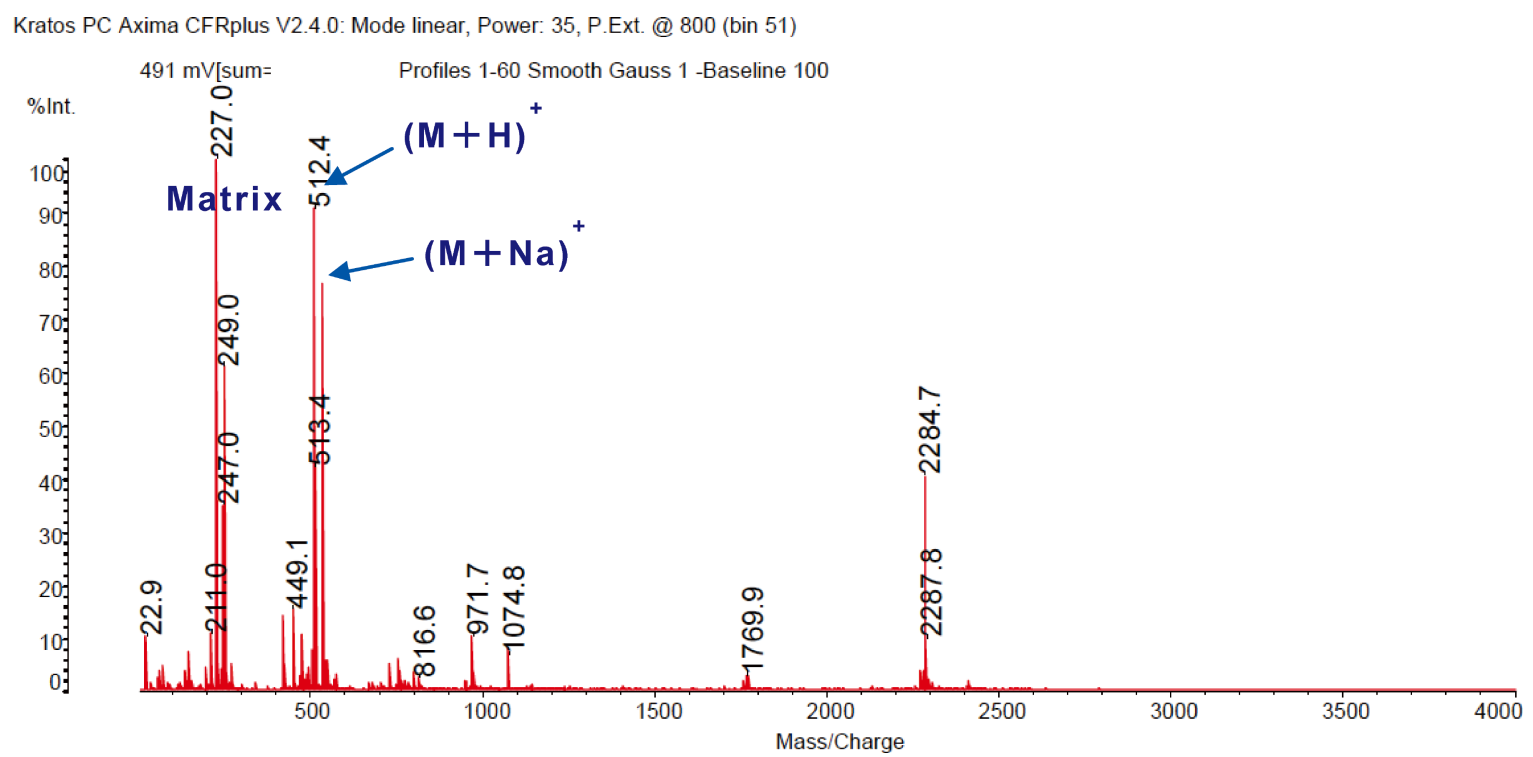

Fig. 2 MALDI-TOFMS spectrum of Tinuvin 850

AXIMA-CFR plus (Shimadzu Corporation) was used. Dithranol and NaI was used as the matrix and the auxiliary agent for ionization, respectively.

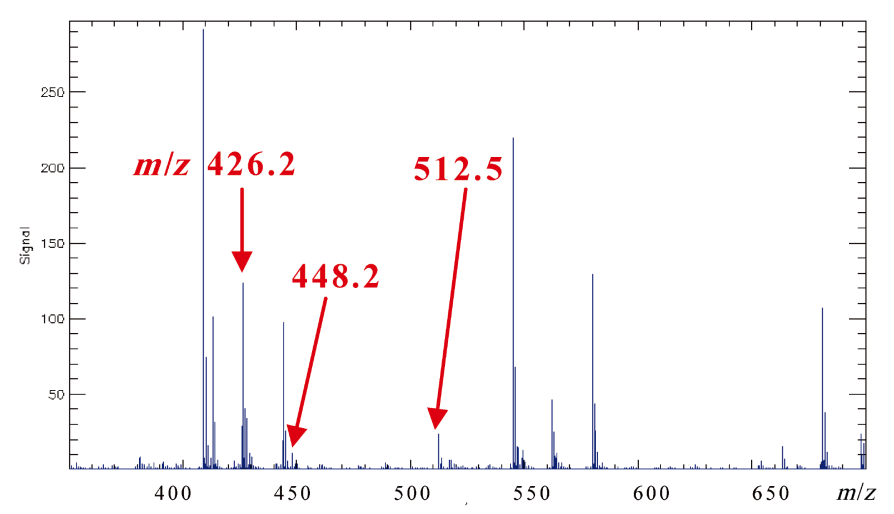

(a)

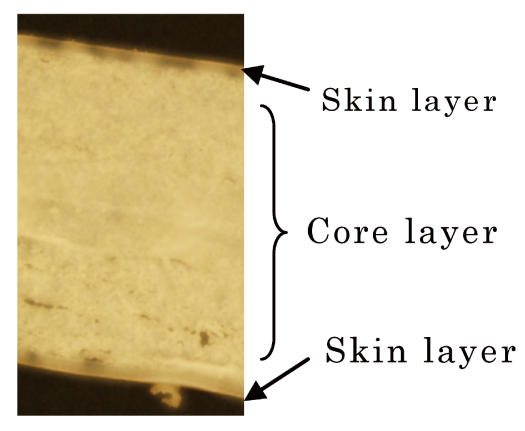

(b)

\section{[Tinuvin 850]}

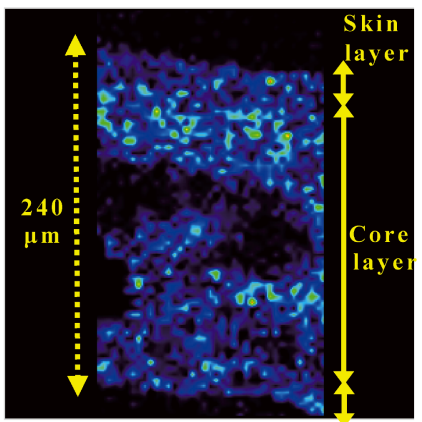

$\mathrm{m} / \mathrm{z} \mathbf{5 1 2 . 5}$

Ionic intensity

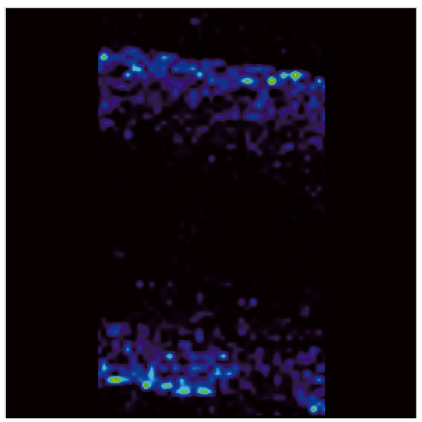

$m / z 448.2$

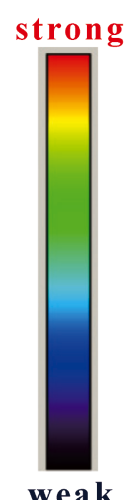

(c)

Fig. 3 MALDI-MS imaging results for a multi-layer optical film

(a) MS spectrum of the film, (b) micrograph transmission image of the cross section, (c) MS mapping images. $\mathrm{m} / \mathrm{z}$ 426.2, 448.2 and 512.5 were used for the mapping of each stabilizer, Tinuvin $1577 \mathrm{~F}$, Tinuvin 234 and Tinuvin 850 respectively. The MS mapping area corresponds to the micrograph transmission image. 


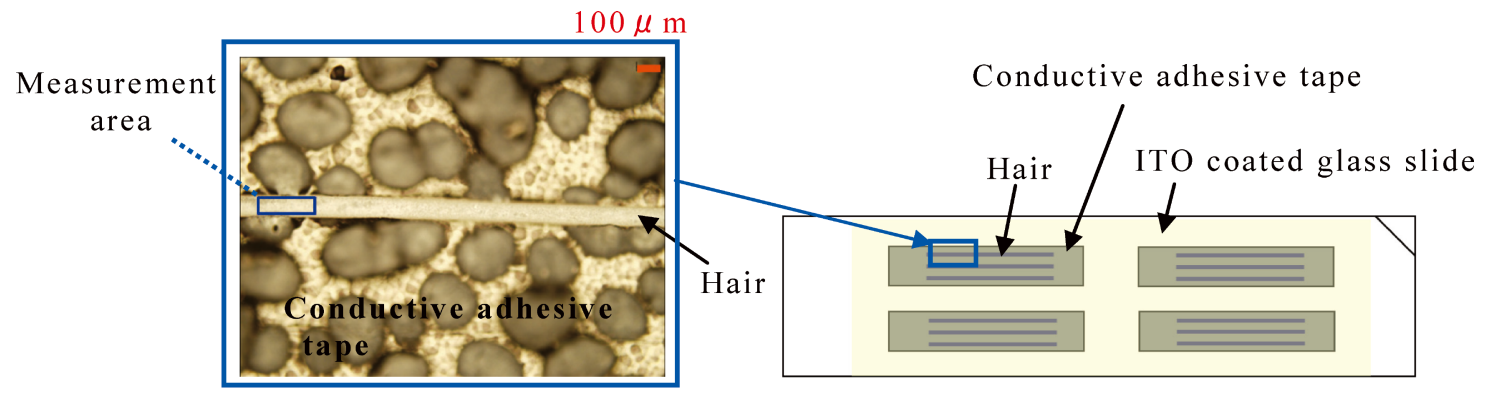

(a)

(b)

Fig. 4 Preparation of a hair sample for a MALDI-MS imaging measurement

(a) Micrograph image of the hair sample fixed with conductive adhesive tape $(\times 10)$, (b) schematic drawing of the hair samples for the measurement. The hair samples were immersed in a hair-care conditioner, and the samples were attached in a parallel manner with conductive adhesive tape on an ITO glass slide. A DHB matrix was then deposited using a sublimation method.

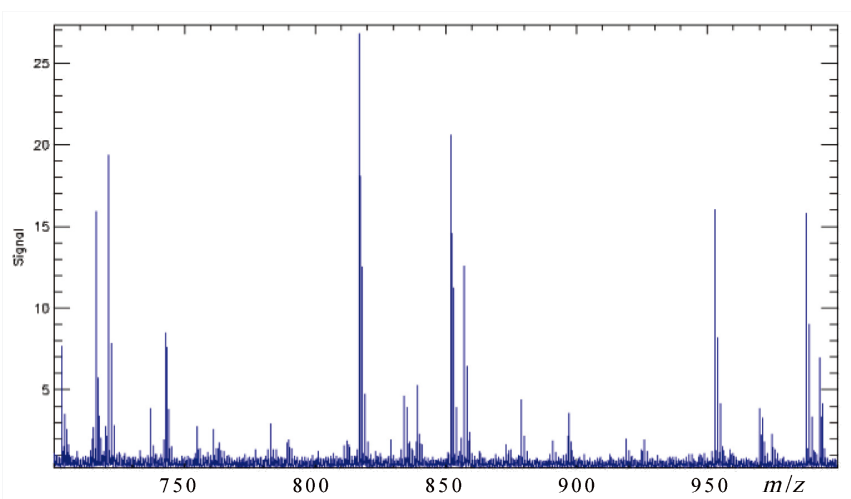

(a)

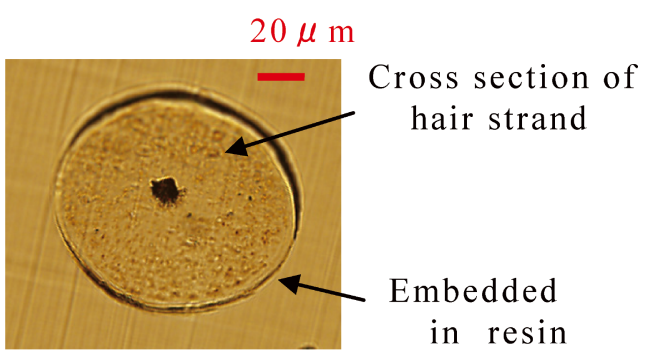

(b)

Fig. 5 MALDI-TOFMS spectrum and micrograph of the hair sample

(a) MS spectrum, (b) micrograph (transmission CCD image) of the hair samples embedded in epoxy resin.

\section{$3 \cdot 2$ ヘアケア剤（リンス）に浸漬した毛髮のイメージ} ング測定

Fig. 4 に示すように, ITO スライドガラスにヘアケア剂 （リンス）を浸漬した毛髪をセットして，毛髪表面の MALDI 積算マススペクトルを測定した. なお, Fig. 5 に示 す各浸漬時間における毛髪断面の積算マススペクトルで見 られた特徵的なイオンと浸漬時間の経過に伴い増加してい くイオンを合わせ, $m / z 791$ と $m / z 703,721,857$ の計四 つのイオンについてイメージング評価を行った. Fig. 6 に 示すように, $m / z 791$ 成分は時間経過と関係なく毛髪表面 に留まっており, また, その他の成分は, 時間経過ととも に毛髪内部から強く検出されるようになっていることが確 認された.

$m / z 791$ 成分は毛髪表面を被覆する成分, その他の成分 は毛髪に浸透していく成分と考えられ, 各成分の構造決定
には至らなかったが，ヘアケア剤（リンス）に含まれる薬 液成分ごとの毛髪への作用を表しているものと推定され た。

$$
4 \text { ま め }
$$

これまで生体材料において行われていた MALDITOFMS によるイメージングを, 合成有機物に適用できな いか検討を行った，その結果，試料の薄膜断面にマトリッ クスとして DHB を均一に蒸着させることで, 今回はフィ ルム中の添加剤として含まれる光安定剤の分布と, 毛髪内 部に浸透していく薬液成分の様子についてイメージ化する ことができた。 このように，本イメージング解析は，一般 的なバルクの分析法では確認できない材料中の化学構造の 分布や偏析状態に関する情報を取得するのに有効な方法で あることが確認された，製品開発においては，時間経過に 


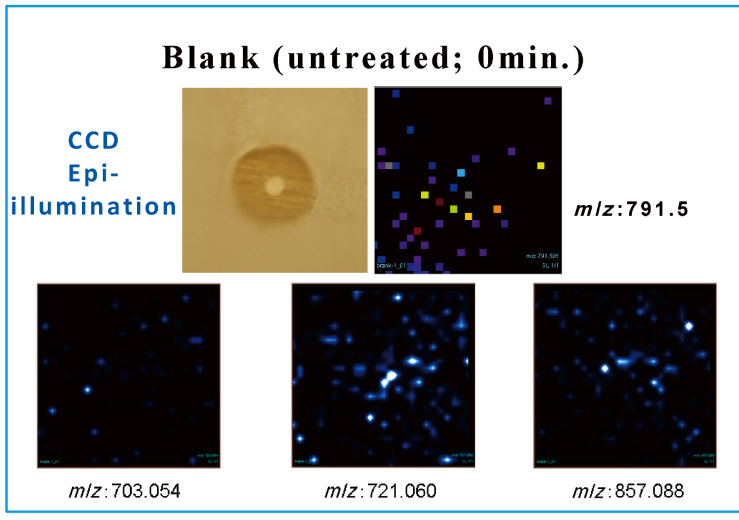

(a)

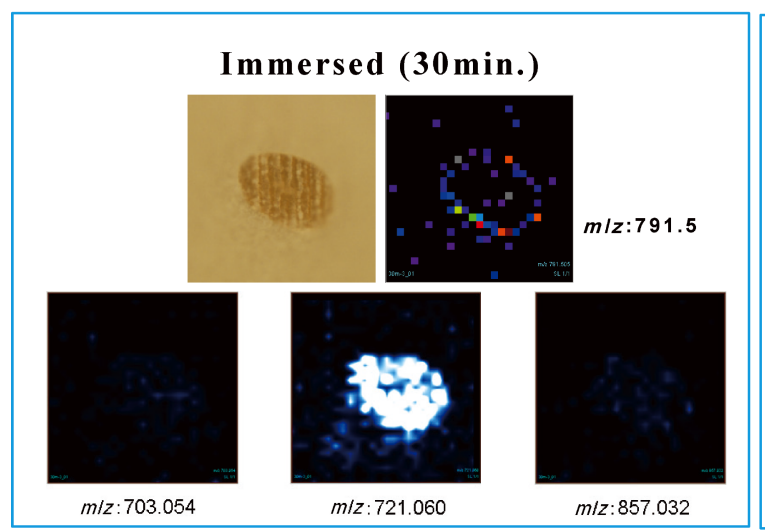

(c)

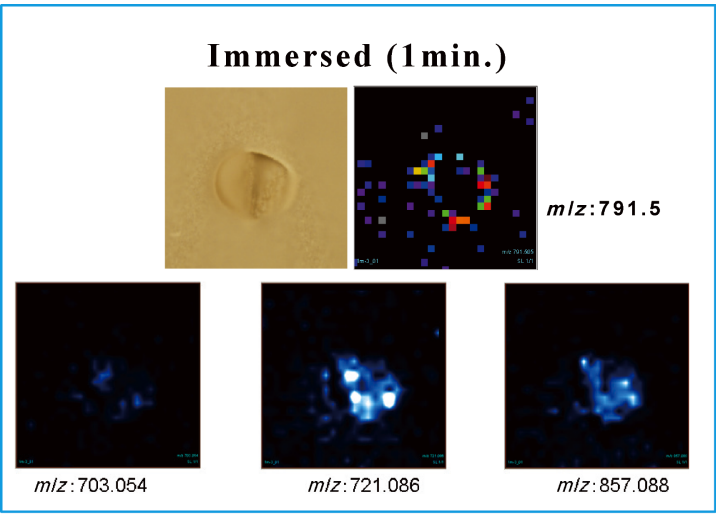

(b)

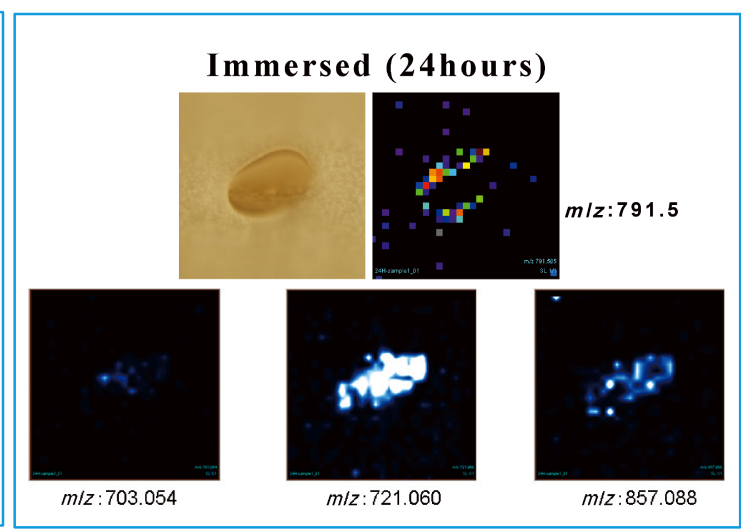

(d)

Fig. 6 MALDI-MS images of the hair cross-section samples

A series of the samples with different immersion times were measured for MALDI-MS imaging. (a) Blank sample (immersion: $0 \mathrm{~min}$ ), (b) after $1 \mathrm{~min}$ immersion, (c) after $30 \mathrm{~min}$ immersion, (d) after 24 hour immersion. For each sample, a micrograph (CCD epi-illumination image, obtained after matrix sublimation) is shown in the upper left. Others are corresponding MALDI-MS images. $\mathrm{m} / \mathrm{z}$ 703.1, 721.1, 791.5, and 857.0 were used for individual mappings.

伴う添加剤のマイグレーションやブリードアウト解析等の メカニズム解明にも活用できると考えられる。

MALDI 法は, マトリックスの付着状態等, 前処理条件が イオン強度を大きく左右することが知られている。 した がって, MALDI-TOFMS を用いて材料系の合成有機成分を イメージングする方法では, 目的成分を効率的にイオン化 させるためのマトリックス種の選択と, 試料上でのマト リックス粒子径や均一性を保つための工夫が必要となり, 蒸着法以外にも噴霧法等, 種々の前処理方法が検討されて いる. また, 切片試料の場合は, 適正な切片作成法はもち ろんのこと, その厚みや導電性の付与法等もイオン化効率 に大きな影響を与え, これらは, 合成有機成分の種類に よってそれぞれ適正な方法が存在する ${ }^{9) \sim 11)}$. 今後, 応用で きる対象材料, 合成有機成分種を拡大していくことで, MALDI-TOFMS によるイメージング法のさらなる発展が 期待される ${ }^{12)}$.
謝 辞

本研究にあたっては，質量顕微鏡（iMScope）の試作機 と蒸着装置を用いた測定にご快諾いただきました侏島津製 作所基盤技術研究所 藤分秀司様に感謝申し上げます.

\section{文献}

1) 西岡利勝, 寶崎達也共編：“実用プラスチック分 析”, p. 476 (2011), (オーム社).

2) 西岡利勝, 寶崎達也共編：“実用プラスチック分 析”, p. 121 (2011), (オーム社).

3) 瀬藤光利 : “質量顕微鏡法”, (2008), (シュプリン ガージャパン).

4) Y. Sugiura, S. Shimma, Y. Moriyama, M. Setou : J. Mass Spectrom. Soc. Jpn., 55, 25 (2007).

5) 原田高宏, 竹内貞夫, 出水秀明, 古橋 治, 竹下建 吾，小河 潔, 吉田恵一, 星川 裕, 瀬藤光利： 島津評論, 64, 139 (2008).

6) S. Shimma, Y. Sugiura, T. Hayasaka, N. Zaima, M. 
Matsumoto, M. Setou : Anal. Chem., 80, 878 (2008).

7) S. M. Weidner, J. Falkenhagen : Rapid Communications in Mass Spectrometry, 23, 653 (2009).

8) T. Harada, A. Yuba-Kubo, Y. Sugiura, N. Zaima, T. Hayasaka, N. Goto-Inoue, M. Wakui, M. Suematsu, K. Takeshita, K. Ogawa, Y. Yoshida, M. Setou : Anal. Chem., 81, 9153 (2009).
9) 平＼cjkstart修：ぶんせき (Bunseki), 2013, 429.

10）新間秀一, 瀬藤光利 : J. Mass Spectrom. Soc.Jpn., 53, 230 (2005).

11) 工藤寿治, 菲澤 崇：日本画像学会誌, 50, 448 (2011).

12) A. Walch, S. Rauser, S. O. Deininger, H. Höfler : Histochemistry and Cell Biology., 130, 321 (2008).

\title{
MALDI-TOFMS Imaging Measurement of Synthesized Organic Components
}

\author{
Koji SATo ${ }^{\circledR 1}$, Kazuyuki Yoshida ${ }^{1}$, Hiroko Morinaga ${ }^{2}$, Ryo YAmaguchI ${ }^{2}$ and Kiyoshi Ogawa ${ }^{2}$ \\ ${ }^{\circledR}$ E-mail : satou.kc@om.asahi-kasei.co.jp \\ ${ }^{1}$ ASAHI KASEI CORPORATION, Analysis \& Simulation Center, 2-1, Samejima, Fuji-shi, Shizuoka 416-8501 \\ ${ }^{2}$ SHIMADZU CORPORATION, Technology Research Laboratory, 3-9-4, Hikaridai, Seika-cho, Soraku-gun, \\ Kyoto 619-0237
}

(Received December 9, 2013; Accepted March 5, 2014)

We performed a study of MALDI-MS imaging that is a combination of an optical microscopy and MALDI mass spectroscopy. Mapping images of chemical materials were successfully obtained by applying 2,5-dihydroxybenzoicacid (DHB) as a matrix with a sublimation method. In this paper, we present two results: (1) the distribution of light stabilizers in a multi-layer synthetic film, and (2) the state of the penetration phenomena of hair conditioner chemical components in the hair shaft. In either case, a careful selection of $m / z$ ion enabled successful mapping for individual components; and a variation of the distribution according to the type of components was revealed. Further, important implications with regard to the development design of the materials structure and chemical components were deduced. These results indicated that the MALDI-MS imaging method, which has been extensively used only for biomaterials, is also a powerful tool for the analysis of chemical materials.

Keywords: MALDI imaging mass spectrometry; mass-microscope; light stabilizer; multi-layer optical film; hair strand; sublimation. 